\title{
Determinants of Employees Job Satisfaction in Polish Enterprises-Findings of Empirical Studies
}

\author{
Anna Lemańska-Majdzik, Małgorzata Okręglicka \\ Czestochowa University of Technology, Poland \\ lemanska@zim.pcz.pl
}

\begin{abstract}
Employees' job satisfaction is influenced by a number of diverse determinants which are related with the work performed by an employee, depend on individual characteristics of an employee, and result from the features of the environment in which a given organisation is functioning. Job satisfaction affects the functioning of an enterprise, its competitiveness and profitability, and high level of employees' satisfaction may be a key factor impacting the success of the whole organisation. The aim of the paper is to show which determinants of job satisfaction, and at what level, can be distinguished among employees of Polish enterprises, depending on selected variables. A questionnaire survey conducted in 2015 on a group of 158 enterprises enabled identification of statistical dependences and verification of formulated research hypotheses which defined, among other things: the impact of the determinants of employees' job satisfaction depending on the age of a company, its size, or period of employment of its employees.
\end{abstract}

Keywords: Employees' job satisfaction, satisfaction determinants, Polish enterprises

\section{Introduction}

Job satisfaction is a central concept in organizational psychology, and research on its determinants and outcomes has strong practical relevance for management of human resources (Hauff, Richter, Tressin, 2015). Job satisfaction is critical to life satisfaction, to the quality of employees' working life, and to their performance and organizational commitment (Moniarou-Papaconstantinou \& Triantafyllou, 2015). Many entrepreneurs attach great importance to satisfaction of an employee, assuming that increased satisfaction will lead to increased work effectiveness. The concepts presenting how job satisfaction is shaped indicate the role of both an organisation and working environment in this process as well as factors that exist in an individual and affect the level of satisfaction. The subject of job satisfaction attracts undiminished interest of both researchers and management practitioners. This results in a number of definitions of the concept of job satisfaction provided by literature. In general, employees' satisfaction is a positive attitude to their enterprise, co-workers and work they do. One of the most widely used definitions in economic literature is that of Locke (1976), who defines job satisfaction as "a pleasurable or positive emotional state resulting from the appraisal of one's job or job experiences". Thus, job satisfaction refers to positive or/and negative feelings and attitudes towards work, shaped by a number of factors connected with one's work, individual factors connected with the person of an employee and characteristics of the environment in which a specific organisation is functioning.

It is pointed out that employees with higher job satisfaction show more initiative, less reluctance to innovations, are more loyal to the company for which they are working, create a specific organisational climate and have a lower level of absence (Bartkowiak, 2009). This impacts not only profitability but also competitiveness of an organisation operating in the conditions of globalisation (Mynarzová \& Kaňa, 2014). Therefore, it is very important to examine job satisfaction and relationships between the different elements of work and job satisfaction. The aim of this paper is to show which determinants of job satisfaction, and at what level, can be distinguished among employees in manufacturing, services and commercial enterprises, depending on the size of a company, how long it has been functioning on the market and how long an employee has been working in a given company. Its aim is also to define possibilities of employees' personal development in various groups of enterprises. The inference performed in this paper is based on findings of questionnaire surveys conducted in 2015 on a group of 158 enterprises carrying out economic activity across Poland. 


\section{Employees' Job Satisfaction and its Determinants in the Process of Functioning of an Organisation - Selected Aspects}

The importance of work in the life of a human being is huge and undeniable, and job satisfaction is one of the most important elements affecting employees' satisfaction, their performance and effectiveness (Potkany, 2008; Potkany \& Giertl, 2013). Bartkowiak stresses that satisfaction is an element of a human being's motivation in a broader sense or well-being, which results from fulfilment of their needs and aspirations (Bartkowiak, 2009). Job satisfaction has turned out to be closely connected with life satisfaction (see Judge, \& Watanabe, 1993). In general, job satisfaction is defined as a positive attitude reflected in an employee's opinion about the work they do and its character (Mincu, 2015). Koys (2003) defines job satisfaction as a way in which an employee perceives and assesses their work, whereas Bernhardt, Donthu and Kennett (2000) claim that job satisfaction refers to more personal feelings and involves a personal evaluation of working conditions as well as results of performed work. According to Herzberg (1987), satisfaction is achieved through the character of work, while dissatisfaction results from work affecting factors, such as remuneration (Conte \&Landy, 2010). Employees' satisfaction affects effectiveness and profitability of an enterprise, and thus implementation of long-term plans of every organisation (Rostkowski, 2004). Research confirms a positive relationship between employees' job satisfaction and their effectiveness, which impacts not only employees' effectiveness at work but also the effectiveness of the whole organisation (Koys, 2001). As Sienkiewicz (2010) stresses, market success in a turbulent environment requires employees that are ready to learn (Gorzeń-Mitka, 2013), as this helps them respond to changes, be creative and easily embrace new work methods or tools. Academic literature also offers empirical studies of the business sector which show a positive relationship between a learning organisation and job satisfaction of its employees (Kurland \& Hasson-Gilad, 2015).

According to Saari and Judge (2004), job satisfaction is a result of a number of factors resulting e.g. from employees' conduct and positive or negative attitude to work. Spector (1997) stresses that job satisfaction that affects employees' satisfaction depends on a range of factors that include remuneration, additional benefits, leadership style, supervision in an organisation, character of the work, as well as personality of coworkers. Steers and Mowday (1981) emphasize that every employee will have a slightly different set of expectations about their work, depending on their own values and needs in a given moment. Therefore, satisfaction factors indicated by employees will vary depending on the character of the organisation itself, the environment in which it functions as well as personal objectives and preferences of an individual employee. Job satisfaction is determined by the microenvironment, including political, social, economic and cultural environment (Kaasa, 2011; Tomski, 2011), as it is hard to separate organisations functioning in a certain environment from their employees. Another factor influencing satisfaction of an organisation's employees is the organisational culture existing in that enterprise. Some studies show a positive relationship between job satisfaction and organisational culture (Lovas, 2007; Fleskova \& Podolcova, 2010; Sipa, 2015) and between running a socially responsible business and satisfaction of employees of organisations implementing sustainable programmes (Fleskova, 2011; Chudy, 2012).

The significance of factors affecting employees' satisfaction can be connected, as Springer (2011) shows in his research, with the position held and type of performed work. A different set of factors will be important and relevant for the lowest-level employees than for specialists or independent employees. Therefore different employees will have different preferences concerning working conditions and will choose work based on different features (Shin, Koh \& Shim, 2015). The choice of the right profession, position at work or work character has a direct impact on an employee's satisfaction, and their criteria for choosing the future job should correspond to their expectations or be closely correlated with them. Ellickson, and Logsdon (2002), in their research into job satisfaction factors, confirmed that there are no differences between sexes as far as general job satisfaction is concerned. The research did not find out a different range of factors for working women and men. Based on multinational research, Hauff, Richter, Tressin (2015) stress that job satisfaction factors will vary across countries. Some factors have equal impact on job satisfaction in different countries, e.g.: high income, good relations with co-workers, whereas other factors vary across the countries examined, e.g. security or chance of promotion. Sense of security, as an important determinant of job satisfaction, can both increase and decrease satisfaction level (Green \& Tsisianis, 2005). 
An important factor affecting job satisfaction is good relations with superiors, who should strive to eliminate employees' discomfort and distrust. Good relations with superiors can affect performance and mutual relations, which in turn leads to better communication in an organisation (Ellickson, Logsdon, 2002). Research by Quintan, Park and Cabrera (2015) shows that the leader of an organisation is significant for and affects employees' satisfaction. A leadership style affects not only the economic result of an enterprise's activity, but also employees' satisfaction, which in turn affects the success of the whole organisation (Havig at el., 2011). The personality of the leader in an organisation, their leadership style, can impact the feelings of employees, who, having different personalities may vary in how they feel job satisfaction. (Yun et al. 2007). Employees' involvement, as another factor impacting success of an organisation, can also depend on employees' job satisfaction. Research by Bhuvanaiah and Ray (2014) shows that the issue of employees' involvement is closely connected with the success of an organisation and practically results from job satisfaction. An uninvolved employee is hardly likely to feel job satisfaction. Employees' job satisfaction can also be connected with how long they have been employed in a given company, as studies indicate that people who have worked in a certain company for a shorter period of time show a higher level of satisfaction with their work compared to those working longer than 15 years (Tomovska-Misoska at el., 2014). Further, job satisfaction has a negative impact on staff's voluntary rotations, which affect operating expenses, especially in enterprises using the latest technologies (Kessler, 2014). There is also a significant difference between parttime and full-time employees in terms of job satisfaction. Full-time employees show a higher level of job satisfaction compared to part-time or temporary employees (Giannikis \& Mihail, 2010).

Research into factors affecting employees' job satisfaction also focused on examining job satisfaction factors of employed and self-employed persons. Research of Blanchflower (2004), Hamermesh (1977), Clark (1996), Clark at el. (1998) among others, shows that self-employment usually gives more pleasure and satisfaction compared to employed persons. A significant role is played here by advantages of self-employment, such as flexible working hours, freedom to take decisions, or lack of a direct superior. One should however bear in mind that not every employed person can function well as a self-employed person, due to the characteristics of self-employment listed as the advantages of self-employment (Lemańska-Majdzik, 2009). It has also been shown that processes taking place in an organisation, understood as a sequence of interrelated actions taken by a specific employee in an organisation to bring intended effects for the enterprise, have an impact on their job satisfaction, due to e.g. the use of technology. It is also important in this case whether given business processes are being implemented in an organisation or only improved (Bala \& Venkatesh, 2013). A different range of determinants will be indicated by employees who, working in an organisation, are implementing a system of process management.

\section{Methodology and characterisation of the study group}

The aim of the survey was to show job satisfaction determinants of employees in manufacturing, services and commercial enterprises operating across Poland, depending on the size of a company, how long a company has been functioning on the market and how long an employee has been working in a given company, and to define the possibilities of employees' personal development. Given the main aim of the paper, the following research hypotheses have been formulated:

- $\mathrm{H} 1$ - in smaller enterprises, job satisfaction determinants have a stronger impact on the increase in a job satisfaction level than in larger companies;

- $\mathrm{H} 2$ - in enterprises that have been functioning on the market for a shorter period of time, job satisfaction determinants have a stronger impact on the increase in a job satisfaction level than in enterprises with a longer history of operation;

- H3 - how long an employee has been working in a given enterprise impacts their selection of job satisfaction determinants.

A statistical analysis of a survey results enabled full or partial verification of the hypotheses formulated. The survey used a purposing sampling. It was conducted in Q1 of 2015 on a group of 158 employees of small, medium-sized and large enterprises operating across Poland. The research tool was a survey questionnaire containing 13 closed questions. The sample was not fully representative, therefore the survey should be treated as pilot research that can be used to further explore the issue in the future by conducting representative research. However, the size of the sample allows initial conclusions to be drawn and 
regularities to be identified. The findings presented in the paper are only a fragment of empirical studies conducted. In order to determine factors affecting employees' satisfaction in various groups of enterprises, 9 selected determinants were diagnosed. For the analysis of the gathered material, a 5-level Likert scale was used, which allowed the authors to obtain a more detailed opinion on the impact of determinants on employees' satisfaction. Relationships between the variables: number of employees, how long a company has been functioning and how long an employee has worked in a given enterprise, and the answers contained in the survey questionnaire on rank scales, i.e. an employee's assessment of the enterprise's position on the market, assessment of an employee's chance to improve their qualifications and selected determinants of job satisfaction, were analysed by calculating Kendall tau rank correlation coefficients. Test probability $\mathrm{p}<0.05$ was considered as significant, whereas test probability $\mathrm{p}<0.01$ was considered as highly significant. The results were analysed using the statistical application PQStat ver. 1.6.

The survey shows that very small companies, i.e. employing up to 9 people, constituted the biggest group of the enterprises whose employees indicated factors impacting job satisfaction, accounting for almost $33 \%$ of the enterprises. They were followed by small enterprises, i.e. employing 10 to 49 people, which accounted for almost $27 \%$ of the enterprises, and large companies, i.e. employing over 250 people, accounting for over $24 \%$ of the enterprises. In total, the SME sector accounted for almost $76 \%$ of the enterprises whose employees were surveyed. The respondents were mainly working in services - this type of activity accounted for almost $37 \%$ of all types of activity, followed by manufacturing (25.3\%) and commercial companies (16.5\%). Overall, the respondents were new employees - almost 32\% of them have been working in the current company for less than a year. The largest group of those surveyed, i.e. 40\%, have worked in the current company from 1 to 5 years, almost $13 \%$ of employees have worked from 5 to 10 years, whereas $16 \%$ - for over 10 years. Among the enterprises, those functioning on the market for over 10 years prevailed and accounted for over $65 \%$, enterprises operating for 5 to 10 years accounted for over $19 \%$, whereas only 4 young companies could be called young.

\section{Results}

Determinants of Employees' Job Satisfaction - Results of Empirical Studies: The survey shows that almost $85 \%$ of employees of the companies surveyed evaluate the position of their company as very good and good, whereas almost $14 \%$ evaluate it as poor and passable. No statistically significant dependence ( $>0.05$ ) was however identified between the evaluation of a company's position on the market, length of its functioning and length of an employee's work in a given enterprise (table 1). Thus, it turns out that such parameters as: the size of a company, length of its functioning on the market or period of employment in a given enterprise has no impact on the evaluation of the position of a company on the market.

Table 1: Position of an enterprise on the market as evaluated by its employees

\begin{tabular}{lllllll}
\hline & $\begin{array}{l}\text { Number } \\
\text { employees } \\
\text { company } \\
\text { tau }\end{array}$ & in & $\begin{array}{l}\text { of } \\
\text { a }\end{array}$ & $\begin{array}{l}\text { How long a company } \\
\text { has been functioning } \\
\text { on the market } \\
\text { tau }\end{array}$ & $\begin{array}{l}\text { How long an employee } \\
\text { has been working in a } \\
\text { company }\end{array}$ \\
\hline $\begin{array}{l}\text { Evaluation of an } \\
\text { enterprise's position } \\
\text { on the market }\end{array}$ & 0.0862 & 0.1080 & 0.0774 & 0.1491 & -0.0216 & 0.6877 \\
Source: Own work based on a survey
\end{tabular}

Source: Own work based on a survey

Among the selected factors impacting satisfaction of enterprises' employees, 9 determinants influencing job satisfaction were distinguished. The survey shows that the determinants impacting job satisfaction most often indicated by the employees surveyed are: sense of security, which scored 4.02, and working conditions, which scored 4.01 on a five-level Likert scale. The factors that were least often indicated by employees were: possibility of promotion, development of career and additional benefits, which on average scored 3.24 and 3.00 . 
Table 2: Determinants of job satisfaction and the size of an enterprise

\begin{tabular}{lll}
\hline \multirow{2}{*}{ Job satisfaction determinants } & \multicolumn{2}{l}{ Number of employees in a company } \\
& tau & $\mathbf{p}$ \\
\hline working conditions & -0.2144 & 0.0001 \\
remuneration & -0.1939 & 0.0003 \\
sense of security & -0.2220 & 0.0000 \\
policy towards employees & -0.1222 & 0.0226 \\
atmosphere at work & -0.1872 & 0.0005 \\
System of rewarding employees, bonuses, etc. & -0.1301 & 0.0152 \\
possibility of promotion, development of career & 0.0703 & 0.1901 \\
investments in the development of an employee & 0.0193 & 0.7185 \\
additional benefits for an employee & 0.0322 & 0.5476 \\
\hline
\end{tabular}

Source: Own work based on a survey

The survey has showed that such determinants as: working conditions, remuneration, sense of security, atmosphere at work, are statistically highly significant and negatively correlated at a moderately low level with the number of employees in an enterprise, i.e. the size of a company. The factors: policy towards employees, system of rewarding employees, bonuses etc. are significant at a low level and negatively correlated with the number of employees in a company (table 2). Thus, it turns out that the smaller an enterprise, the more often the above-mentioned factors are indicated as ones impacting employees' satisfaction.

Table 3: Job satisfaction determinants vs. how long a company has been functioning on the market

\begin{tabular}{lll}
\hline Job satisfactiondeterminants & \multicolumn{2}{l}{$\begin{array}{l}\text { How long a company has been functioning } \\
\text { on the market } \\
\text { tau }\end{array}$} \\
\hline working conditions & $-0,2571$ & $\mathbf{p}$ \\
remuneration & $-0,1782$ & 0.0000 \\
sense of security & $-0,1104$ & 0.0009 \\
policy towards employees & $-0,1107$ & 0.0395 \\
atmosphere at work & $-0,1592$ & 0.0391 \\
System of rewarding employees, bonuses, etc. & $-0,1897$ & 0.0030 \\
possibility of promotion, development of career & $-0,0119$ & 0.0004 \\
investments in the development of an employee & $-0,1388$ & 0.8249 \\
additional benefits for an employee & $-0,1037$ & 0.0096 \\
\hline
\end{tabular}

Source: Own work based on a survey

The survey shows that how long a company has been functioning on the market, i.e. its age, is significant when evaluating the impact of selected factors on employees' job satisfaction. As many as 7 out of 9 determinants proved to be statistically highly significant $(p<0.01)$ or significant $(p<0.05)$ with the period of functioning of an enterprise on the market. In all the cases, a negatively correlated dependence was observed at a rather low level, only in the case of working conditions it was at a moderate level (tau=-0,2571) (table 3). In enterprises that have been functioning on the market for a shorter period of time, higher frequency of factors indicated as impacting satisfaction was observed, i.e. in young companies employees indicated more factors that impacted their job satisfaction, whereas in enterprises that have been functioning on the market for a longer period of time, a much lower frequency of indicating job satisfaction factors was observed. 
Table 4: Determinants of job satisfaction vs. how long an employee has been working in the company

\begin{tabular}{|c|c|c|}
\hline \multirow[t]{2}{*}{ Job satisfactiondeterminants } & \multicolumn{2}{|c|}{$\begin{array}{l}\text { How long an employee has been working ir } \\
\text { the company }\end{array}$} \\
\hline & tau & $\mathbf{p}$ \\
\hline working conditions & -0.0820 & 0.1263 \\
\hline remuneration & -0.0041 & 0.9390 \\
\hline sense of security & 0.0940 & 0.0798 \\
\hline policy towards employees & $-0,0528$ & 0.3250 \\
\hline atmosphere at work & -0.1961 & 0.0003 \\
\hline System of rewarding employees, bonuses, etc. & -0.0094 & 0.8611 \\
\hline possibility of promotion, development of career & -0.0816 & 0.1280 \\
\hline investments in the development of an employee & 0.0972 & 0.0699 \\
\hline additional benefits for an employee & 0.0759 & 0.1571 \\
\hline
\end{tabular}

Source: Own work based on a survey

The survey of a group of employees of enterprises operating across Poland shows that the period of employment of an employee is not very significant statistically when evaluating factors impacting employees' satisfaction. Only in the case of the 'atmosphere at work' determinant, statistically highly significant dependence was observed $(\mathrm{p}=0.0003)$. This dependence is negatively correlated at a moderately low level and means that the shorter the period of employment of an employee, the more often atmosphere at work is indicated as significant and determines job satisfaction of an employee (table 4). The survey shows that the evaluation of the possibilities of personal development through improvement of skills, competences and professional qualifications by an employee is statistically highly significant $(p=0.003)$ with the size of an enterprise. It turns out that the evaluation of the possibilities of employees' personal development is negatively correlated, though at a rather low level, with the number of employees, i.e. the more employees an enterprise employs, the less possibilities of improving qualifications.

Table 5: Possibilities of employees' personal development

\begin{tabular}{|c|c|c|c|c|}
\hline & $\begin{array}{l}\text { Number } \\
\text { employees in } \begin{array}{r}\text { of } \\
\text { company } \\
\text { tau }\end{array}\end{array}$ & $\begin{array}{l}\text { How long a company } \\
\text { has been functioning on } \\
\text { the market } \\
\text { tau }\end{array}$ & $\begin{array}{l}\text { How lon } \\
\text { has been } \\
\text { company } \\
\text { tau }\end{array}$ & $\begin{array}{l}\text { employee } \\
\text { orking in a } \\
\text { p }\end{array}$ \\
\hline 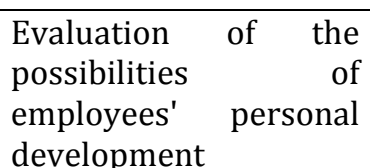 & -0.1591 & 0.0861 & 0.0260 & 0.6284 \\
\hline
\end{tabular}

Source: Own work based on a survey

Such dependence was not observed in the case of the length of functioning of a company on the market and period of employment in a given enterprise (table 5).

\section{Conclusion}

The aim of the survey of a group of very small, small, medium-sized and large enterprises operating across Poland was to show job satisfaction determinants of employees in enterprises functioning across Poland depending on the size of a company, how long a company has been functioning on the market and how long an employee has been working in a given company, as well as to define possibilities of employees' personal development. The factors affecting job satisfaction that were most often indicated in the questionnaire survey include: sense of security, which scored 4.02, and working conditions, which scored 4.01 on a 5-level scale, whereas the least often indicated factors include: possibility of promotion, development of career and additional benefits, which on average scored 3.24 and 3.00. Parameters such as the size of a company, how long it has been functioning on the market and period of employment of an employee in a given enterprise do not impact employees' evaluation of the market position of the enterprise they work for. It has also been found out that the more employees an enterprise employs, i.e. the bigger it's size, the less possibilities of 
personal development of its employees. According to those surveyed, development possibilities in smaller companies are much greater.

The survey enabled verification of the research hypotheses formulated in the paper, namely:

- H1 has been partially confirmed; it has been found out that such determinants as: working conditions, remuneration, sense of security, atmosphere at work, are statistically significant and negatively correlated at a moderately low level with the number of employees in an enterprise, i.e. the size of a company; it has been found that the smaller an enterprise, the more often the above mentioned factors are indicated as impacting satisfaction of employees.

- $\mathrm{H} 2$ has been confirmed in general, as 7 out of 9 determinants have been found out to be statistically highly significant or significant with the length of an enterprise's functioning on the market - in all the cases, a negatively correlated dependence was observed at a rather low or moderate level; in enterprises that have been functioning on the market for a shorter period of time, satisfaction impacting factors were indicated more frequently, i.e. in young companies, employees indicated more factors that impacted their job satisfaction.

- H3 has generally not been confirmed, as the period of employment of an employee is not very significant statistically when evaluating factors impacting employees' satisfaction; only in the case of 1 out of 9 determinants a statistically highly significant dependence negatively correlated at a moderately low level was observed, which means that the shorter the period of employment of an employee, the more often atmosphere at work is indicated as significant and determining an employee's job satisfaction.

It is worth considering carrying out a similar survey on a representative group of enterprises or groups of enterprises in different countries in order to find regularities and present recommendations.

\section{Reference}

Bala, H. \& Venkatesh, V. (2013). Changes in employees' job characteristics during an enterprise system implementation: A latent growth modeling perspective. MIS Quarterly, 37(4), 1113-A7.

Bartkowiak, G. (2009). Człowiek w Pracy. Od Stresu do Sukcesu w Organizacji, PWE Warszawa, 103-104.

Bernhardt, K. L., Donthu, N. \& Kennett, P. A. (2000). A Longitudinal Analysis of Satisfaction and Profitability. Journal of Business Research, 47(2), 161-171.

Bhuvanaiah, T. \& Raya, R.P. (2014). Employee Engagement: Key to Organizational Success. SCMS Journal of Indian Management, 11(4), 61-71.

Blanchflower, D. G. (2004). Self-employment: More may not be better. Swedish Economic Policy Review, 11(2), 15-74.

Chudy, K. (2012). The Strategy of Social Responsibility and Human Resource Management. [in:] S. Gostkowska-Dźwig, (ed.). Przedsiębiorczość. Wydawnictwo WZ PCz, Częstochowa.

Clark, A. E. (1996). Job satisfaction in Britain. British Journal of Industrial Relations, 34(2), 189-217.

Clark, A. E., Georgellis, Y. \& Sanfey, P. (1998). Job satisfaction, wage changes and quits: Evidence from Germany. Research in Labor Economics, 17, 95-121.

Ellickson, M. C. \& Logsdon, K. (2002). Determinants of Job Satisfaction of Municipal Government Employees. Public Personnel Management, 31(3), 343.

Fleskova, M. (2011). Spokojnost'azamestnancovverejnejspravy s pracovnymipodmienkamiako jeden zosocialnychaspektovspoločenskyzodpovednehopodnikania. Economic, Social, Environmental and Legislative Aspects of the Corporate Social Responsibility I. BanskaBystrica: EF UMB.

Fleskova, M. \& Podolcova, M. (2010). Podnikovakultúra a pracovnaspokojnost'azamestnancov, [in:] T. Búgel'ova, G. Kravčakova, (eds.) Hodnotadusevnejprace pre organizaciu a spoločnost'. Kosice, 86-98.

Giannikis, S. K. \& Mihail, D. (2010). Modelling job satisfaction in low-level jobs: Differences between full-time and part-time employees in the Greek retail sector. European Management Journal, 29, 129-143.

Gorzeń-Mitka, I. (2013). Doskonalenie jako paradygmat zarządzania współczesnym przedsiębiorstwem, [in:] Problemy doskonalenia zarządzania przedsiębiorstwem. Gorzeń-Mitka I. (ed.). Sekcja Wydaw. WZ PCzęst. Częstochowa, 11-21.

Green, F. \& Tsisianis, N. (2005). An investigation of national trends in job satisfaction in Britain and Germany. British Journal of Industrial Relations, 43(3), 401-429. 
Hamermesh, D. S. (1977). Economic aspects of job satisfaction, [in:] O. Ashenfelter, W. Oates (eds.), Essays in labor market analysis. New York: Wiley.

Hauff, S., Richter, N. F. \& Tressin, T. (2015). Situational job characteristics and job satisfaction: The moderating role of national culture. International Business Review, 24(4), 710-723.

Havig, A. K., Skogstad, A., Veenstra, M. \& Romoren, T. I. (2011). The effects of leadership and ward factors on job satisfaction in nursing homes: a multileveled approach. Journal of Clinical Nursing, 20, 3532-3542.

Herzberg, F. (1987). One more time: How do you motivate employees? Harvard Business Review, 65(5), 109120.

Judge, T. A. \& Watanabe, S. (1993). Another look at the job satisfaction-life satisfaction relationship. Journal of Applied Psychology, 78(6), 939-948.

Kaasa, A. (2011). Work values in European countries: Empirical evidence and explanations. Review of International Comparative Management, 12, 852-862.

Kessler, L. L. (2014). The effect of job satisfaction on IT employees turnover intention in Israel, Annals of the University of Oradea. Economic Science Series, 23(1), 1028-1038.

Koys, A. J. (2003). How the achievement of human resources goals drives restaurant performance. Cornell Hotel and Restaurant Administration Quarterly, 44, 17-24.

Koys, D. J. (2001). The effects of employee satisfaction, organizational citizenship behavior, and turnover on organizational effectiveness: A unit-level, longitudinal study. Personnel Psychology, 54(1), 101-114.

Kurland, H. \& Hasson-Gilad, D. R. (2015). Organizational learning and extra effort: The mediating effect of job satisfaction. Teaching and Teacher Education, 49, 56-67.

Landy, F. J. \& Conte, J. M. (2010). Work in the 21st Century: An Introduction to Industrial and Organizational Psychology (Third Edition).Hoboken, NJ: Wiley-Blackwell.

Lemańska-Majdzik, A. (2009). Czynniki sukcesu firm powstałych w wyniku samozatrudnienia, Sekcja Wydawnicza Wydziału Zarządzania Politechniki Częstochowskiej.

Locke, E. A. (1976). The nature and causes of job satisfaction, [in:] M.D. Dunnette (ed.), Handbook of industrial and organizational psychology. Chicago: Rand McNally, 1297-1349

Lovas, L. (2007). Relationship of organizational culture and job satisfaction in the public sector. Studia Psychologica, 49(3), 215-221.

Mincu, C. L. (2015). The impact of personal resources on organizational attitudes: Job satisfaction and trust in organization. Procedia - Social and Behavioral Sciences, 187, 685-689.

Moniarou-Papaconstantinou, V. \& KalliopiTriantafyllou, K. (2015). Job satisfaction and work values: Investigating sources of job satisfaction with respect to information professionals. Library \& Information Science Research, 37, 164-170.

Mynarzová, M. \& Kaňa, R. (2014). Theory and Practice of Industrial Policy of the EU in the Context of Globalization Challenges, [in:] I. Honová, et al., (Eds.). Proceedings of the 2nd International Conference on European Integration 2014. Ostrava: VŠB - Technical University of Ostrava, 499-507.

Potkany, M. (2008). Personnel outsourcing processes. Ekonomie a management: vedeckyekonomickycasopis, 11(4), TU Liberec, 53-62.

Potkany, M. \& Giertl, G. (2013). Statistical prognosis of basic business performance indicators in the wood processing industry of the Slovac Republic, [in:] Markets for wood and wooden products, Zagreb: WoodEMA, 31-56.

Quintana, T., Park, S. \& Cabrera, Y. (2015). Assessing the Effects of Leadership Styles on Employees' Outcomes in International Luxury Hotels. Journal of Business Ethics [serial online]. June 26, 2015; 129(2), 469489. Available from: Business Source Complete, Ipswich, MA. Accessed July 1, 2015.

Rostkowski, T. (2004). Nowoczesne metody zarządzania zasobami ludzkimi, Difin, Warszawa 2004, 183.

Saari L. M. \& Judge, T. A. (2004). Employee attitudes and job satisfaction. Human Resource Management, 43(4), 395-407.

Shin, Y. B., Koh, S. H. \& Shim, C. S. (2015). Information processing model to measure important determinants on job satisfaction. Journal of Business \& Retail Management Research, 9(2), 100-109.

Sienkiewicz, Ł. (2010). Rola szkoleń i rozwoju w budowaniu innowacyjności pracowników i przedsiębiorstwa, [in:] S. Borkowska (ed.), Rola ZZL w kreowaniu innowacyjności organizacyjnej, C.H. Beck, Warszawa, 131-151.

Sipa, M. (2015). Postrzeganie kultury organizacji przez pracowników przedsiębiorstw rodzinnych i nierodzinnych - wybrane aspekty, [in:] Firmy rodzinne - doświadczenia i perspektywy zarządzania (ed.) Ł. Sułkowski, A, Mariański. Przedsiębiorczość i Zarzq̨dzanie, 16(7), 103-117. 
Spector, P. (1997). Job satisfaction: Applicatio, assesment, cause and consequences. Thousand Oaks, CA: Sage. Saleem H. (2015). The impact of leadership styles on job satisfaction and mediating role of perceived organizational politics. Procedia - Social and Behavioral Sciences, 172, 563-569.

Springer, A. (2011). Wybrane czynniki kształtujące satysfakcję pracownika. Problemyzarządzania, 9, 4(34), 162-168.

Steers, R. M. \& Mowday, T. T. (1981). Employee Turnover and Post-decision Accommodation Processes, [in:] Cummings, L.L., Staw, B.M., (Eds). Research in Organizational Behavior. Grenwich, CT: JAI Press.

Tomovska-Misoska, A., Stefanovska-Petkovska, M., Ralev, M. \& Krliu-Handjiski, V. (2014). Workspace as a factor of job satisfaction in the banking and ICT industries in Macedonia. Serbian Journal of Management, 9(2), 159-171.

Tomski, P. (2011) Paradygmat hiperdynamiki otoczenia a współdziałanie gospodarcze współczesnych przedsiębiorstw, Zeszyty Naukowe Politechniki Częstochowskiej. Zarządzanie, 1, 7-18.

Yun, S., Cox, J., Sims, H. \& Salam, S. (2007). Leadership and Teamwork: The Effects of Leadership and Job Satisfaction on Team Citizenship. International Journal of Leadership Studies, 2(3), 171-193. 